\title{
Identification of the main driving mechanisms in the evolution of a small coastal wetland (Traba, Galicia, NW Spain) since its origin 5,700 cal yr BP
}

\author{
Bao, R.*, Alonso, A., Delgado, C. and Pagés, J. L. \\ Facultade de Ciencias, Universidade da Coruña, Campus da Zapateira s/n, E-15071 A Coruña, Spain \\ * Corresponding author (E-mail address: xerobert@udc.es. Fax: 349811670 65)
}

Palaeogeography, Palaeoclimatology, Palaeoecology 247 (2007) 296-312

Received 19 June 2006; received in revised form 25 October 2006; accepted 27 October 2006

\section{How to cite:}

Bao, R., Alonso, A., Delgado, C., Pagés, J.L., 2007. Identification of the main driving mechanisms in the evolution of a small coastal wetland (Traba, Galicia, NW Spain) since its origin 5700 cal yr BP. $\begin{array}{llll}\text { Palaeogeography, } \quad \text { Palaeoclimatology, } & \text { Palaeoecology } & 247, & \text { 296-312. }\end{array}$ http://dx.doi.org/10.1016/j.palaeo.2006.10.019

\begin{abstract}
This paper examines the interdependence among the different forcing factors in the evolution of the Traba coastal wetland (Galicia, NW Spain) based on lithofacies and diatom analyses of three cores reaching the basement. According to radiocarbon data, the wetland originated 5,700 cal $\mathrm{yr} \mathrm{BP}$, a time when similar systems on the Atlantic coast of the Iberian Peninsula were formed. Diatom assemblage data allow the estimation of the sea level position at 5,700 cal $\mathrm{yr}$ BP at least $7 \mathrm{~m}$ below present-day mean sea level. Attenuation of the sea-level rise at that time was a major driving mechanism that permitted the establishment of an incipient beach-dune complex, causing water-logging in the Traba basin. However, the location of this incipient wetland on a basement high, which prevented an open connection to the sea, made topographic inheritance the main forcing factor in the subsequent evolution of the wetland. Thus, Traba was never a coastal lagoon system, as it has sometimes been defined. The maximum permeability of the beach-dune complex enclosing the wetland was recorded after its origin until 2,900 cal yr BP, when increased stormy conditions affected the Galician shelf waters. Since then, the evolution of the wetland has been mainly controlled by more local factors, especially the continental sediment supply. Changes in land use in the basin have accelerated the infilling of the water body since the 19th century. This rapid infilling makes the whole system more prone to total encroachment in the short term, rather than to sea drowning. Palaeoenvironmental analyses showing the main trends in the long-term evolution of coastal wetlands can be of key importance in any management decisions aimed at preserving these kinds of sensitive coastal environments.
\end{abstract}

Key words: Coastal evolution; Coastal palaeoenvironments; Sea-level change; Sediment supply; Diatoms, Holocene 


\section{INTRODUCTION}

Back-barrier coastal wetlands are environments very sensitive to external forces, such as the presentday accelerated sea-level rise, increased storm activity, and human interference (De Groot and Orford, 2000). Many of these environments can be included in the definition of coastal lagoons (Kjerfve, 1994), the morphodynamics of which are forced by both barrier processes, such as erosion and translation, and back-barrier processes, such as accretion, fluvial delta progradation, and marine sedimentation (Cooper, 1994). The relative importance of each of these factors will determine the future evolution of the system, which will thus be the result of processes resulting in the increase of the size of the lagoon and those which act to reduce it. Therefore, evolutionary models should consider the complex interplay between the different macroscale (sea-level changes, climate, and tectonic stability) and microscale physical processes (sediment supply, topographical inheritance, wave energy, and tidal range) driving the behaviour of these systems (Cooper, 1994; Isla, 1995; Hesp and Short, 1999).

Most wetlands on the Atlantic Iberian coast are considered to have formed as a result of coastal embayment flooding during the Holocene transgression and the formation of a barrier with the deceleration of the sea-level rise since 6,500-5,500 cal yr BP (Bao et al., 1999; Freitas et al., 2003; Freitas and Andrade, 2005). However, very little is known about the particular evolution of the small coastal wetlands of the Galician coastline (NW Spain), which comprise a great variety of small water bodies that range from permanently open to almost closed to the sea. These have traditionally been classified as lagoon systems (Vilas and Rolán, 1985).

The mesotidal coast of Galicia is subject to highenergy waves and storms that could potentially drive the destruction of its back-barrier wetlands. Vilas et al. (1991) noted that the drowning of beaches and salt marshes because of sea-level rises appears to have been a general process in the lagoon complexes of western Galicia over the last 2,000 years. In contrast, other evidence suggests that coastal barriers in this region have been relatively stable or have even prograded during the same period (Devoy et al., 1996). Identification of the precise role that each forcing factor has had on the evolution of the Galician coastal wetlands, which are of great conservation significance, is therefore essential to any understanding of their final fate and to the establishment of effective management guidelines for these ecosystems.

Microfossil stratigraphies can provide a longterm perspective on environmental change, which is useful for an understanding of ecosystem disturbance (Anderson, 1995; Smol, 2002). Several palaeoenvironmental proxies can be used to trace the factors that influence the Holocene history of coastal environments. Diatom analysis in particular has proven to be a very valuable technique (Anderson and Vos, 1992; Denys and De Wolf, 1999). Diatoms are very sensitive indicators of changes in sea and palaeotidal levels (e.g., Zong and Horton, 1999), basin isolation because of isostasy (e.g., Kjemperud, 1986; Saulnier-Talbot and Pienitz, 2001), barrier stability in coastal lagoons (e.g., Bao et al., 1999), storm-surge histories (e.g., Parsons, 1998; Zong and Tooley, 1999), and tsunami activity (e.g., HemphillHaley, 1996). Therefore, diatom stratigraphies can provide relevant data on some of the main forcing factors that have affected coastal evolution in the past.

The Traba coastal wetland (Galicia, NW Spain) was declared part of a Site of Community Importance under the Habitats Directive of the European Union. Effective management decisions on coastal systems require a good knowledge of their long-term controls, both natural and human (Lozano et al., 2004). Those decisions are of primary importance in special protection areas, and coastal wetland evolutionary models can thus play an important role in correct management practices. The aim of this paper was to determine the most general trends in the evolution of the Traba backbarrier coastal wetland and to identify the forcing mechanisms that have driven the major changes in the system since its origin. We present an evolutionary model that can be tested in the future for similar coastal systems and that may be useful for any future management decisions regarding the region. 


\section{SETTING}

Galicia (NW Spain) has a typical mesotidal wave-dominated coast. It receives north-western swell waves with modal periods of 9.2-12 s and median wave heights of $1.7-3.2 \mathrm{~m}$. Storm waves usually exceed a height of $10 \mathrm{~m}$, with maximum values of $18 \mathrm{~m}$. Spring tides, which reach $4.40 \mathrm{~m}$, are an important factor in the coastal dynamics because they magnify the effects of waves in sensitive areas (Masselink and Turner, 1999).

The morphology of the coastline is predominantly inherited from former high stands, except in those parts of the coast where erosive processes have been very active. Last Interglacial palaeogeographic reconstructions (Alonso and Pagés, 2000) have shown that sediments corresponding to beaches from that period, 2-3 m above the present-day mean sea level, are currently being exhumated in palaeocliffs and destroyed by intense wave erosion. Debris flows, landslides, and immature fluvial sediments accumulated at the base of the ancient cliffs during the low sea-level conditions of the Last Glacial period. River valleys and weathered depressions were scoured and emptied of sediments by currents that drained the continent across the coastal plain, at this time 7-20 $\mathrm{km}$ wide, that bordered the old cliffy coast.

The coastal plain was flooded during the Postglacial, and estuaries were inundated at the beginning of the Holocene. Dating the marine deposits at the outermost positions of the estuaries has given dates of 9,000 cal $\mathrm{yr} \mathrm{BP}$, whereas innermost deposits have been dated at 7,500 cal yr BP (Alonso et al., 2000; Pagés et al., 2003; Alonso et al., 2003). The sea-level rise was fast during the early Holocene (8,000-6,000 cal yr BP), decelerating thereafter (Pagés et al., 2005). This deceleration caused the replenishment of the estuaries and the formation of several complexes of beach-barrier wetlands on the most open parts of the coast. Some of the systems formed at that time probably never had a permanent connection to the sea, because they were formed in zones where the basement was higher than the position of the sea level during the mid Holocene.

The Traba coastal wetland $\left(43^{\circ} 11^{\prime} 15^{\prime \prime} \mathrm{N}\right.$; $9^{\circ} 03^{\prime} 20^{\prime \prime} \mathrm{W} ; 4.30 \mathrm{~m}$ above mean sea level) (Fig. 1), located in a sector known in Galicia as the Death Coast, is at present a shallow water body with a maximum depth of 1.5-2 m, an average $\mathrm{pH}$ of 6.9, and conductivity ranging from 230 to $340 \mu \mathrm{S} \mathrm{cm}^{-1}$. The average precipitation in the area is around $1,200-1,400 \mathrm{~mm}$ per year, and the mean temperature ranges from $10-12{ }^{\circ} \mathrm{C}$ in winter to $20{ }^{\circ} \mathrm{C}$ in summer (Martínez Cortizas and Pérez Alberti, 1999). The wetland receives freshwater inputs from two small streams that drain a catchment of 1,200 ha. The catchment is carved in a fracture zone between two granitic massifs where the regolith was evacuated, modelling a rocky flat that was open to the ocean. The present-day wetland, of approximately $10 \mathrm{ha}$, is irregularly elongated and parallel to the coastline. It is closed by a $2 \mathrm{~km}$ length and $400 \mathrm{~m}$ wide beachdune complex, with sand dunes extending in a NE$\mathrm{SW}$ direction. The wetland is drained by a $1 \mathrm{~km}$ long outlet that runs parallel to the sand barrier. This sand barrier appears to have been stable for the last 1,500 years or subject to only small-scale changes, including periods of progradation (Devoy et al., 1996). According to Vilas and Rolán (1985), only in times of extreme storm events does the sea penetrate into the water body through the inlet. A current phase of landward sand mobility has been recorded, suggesting a possible increase in wave energy and storminess in the region (Devoy et al., 1996).

The wetland is partly occupied by a reed swamp consisting mainly of Phragmites australis, Typha latifolia, and Scirpus lacustris. Cladium mariscus also intercalates with the former species in the marginal areas of the reed swamp. Most accreted areas of the wetland are occupied by a swamp scrub and forest community dominated by Salix atrocinerea and Alnus glutinosa. The wetland has been substantially modified in very recent times by land reclamation, which entailed the channelization of the major river course. 


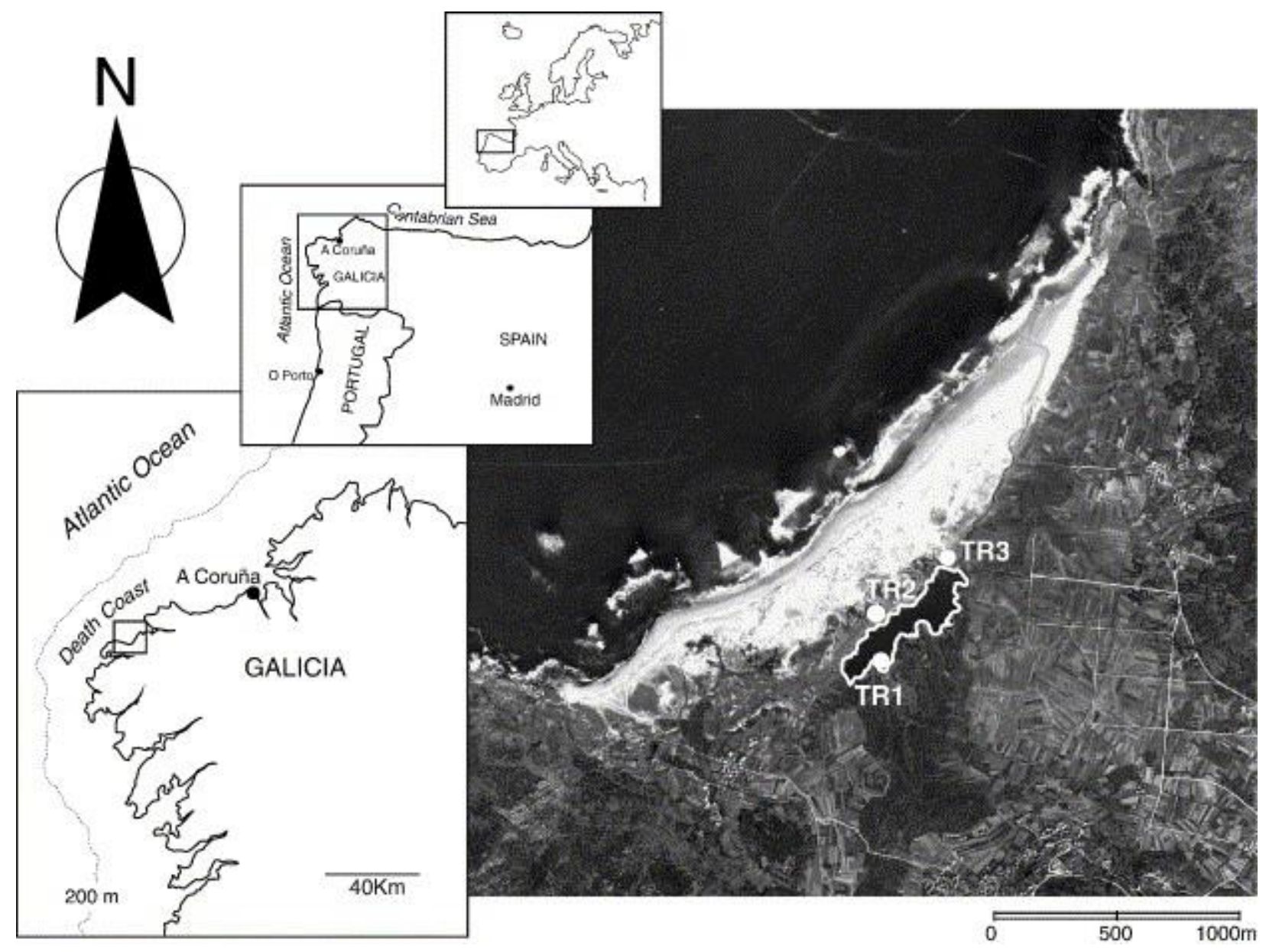

Fig. 1. Location map of the Traba coastal wetland showing coring sites.

\section{MATERIALS AND METHODS}

Three continuous cores reaching the basement were obtained with a motorized rotary corer of 10 $\mathrm{cm}$ diameter, along the principal axis of the wetland, after a previous mapping of the sedimentary system (Fig. 1). The positions of the coring sites and their heights with respect to the present-day mean sea level were measured with a Pentax PTS-II 20F/20C total station. The cores were wrapped in plastic film and stored at $4{ }^{\circ} \mathrm{C}$. They were macroscopically described and sampled every $10 \mathrm{~cm}$. Samples for sedimentological analyses were dried, weighted and seized through $1 \mathrm{~mm}$ and $63 \mu \mathrm{m}$ meshes. The coarser fractions were studied with a binocular microscope. Shape, sorting and nature of sand grains were described.

Cross-correlation among the three cores was established by distinct lithologies. The chronology of the cores was estimated by standard ${ }^{14} \mathrm{C}$ dating of the bulk organic matter, performed by BETA Analytic Inc., USA. The dates were calibrated (2 $\square$; 95\% probability) using the INTCAL04 data set (Reimer et al., 2004) implemented in the CALIB 5.01 software package.

A total of 92 samples from the three cores were checked for diatom content and other siliceous microfossils. Approximately $0.2 \mathrm{~g}$ of dry sediment was collected per sampled stratigraphic level and prepared by standard procedures (Renberg, 1990). Slides were mounted with Naphrax®. Between 300 and 400 valves were counted per sample at a magnification of X1000 using a Nikon Eclipse 600 microscope with Nomarski differential interference contrast optics. Raw valve counts were converted to percentage abundance data. Taxa were mainly identified according to Krammer and Lange-Bertalot (1986-1991), Witkowski et al. (2000), Krammer (2000; 2002; 2003) and Lange Bertalot (2001), among other taxonomic sources. 
Because of the lack of any diatom-based transfer function constructed for the coastal environments of the region, the palaeoenvironmental reconstruction has been based on the grouping of diatoms according to their life form and salinity tolerance (Vos and De Wolf, 1993). Autoecological information for each taxa was mainly obtained from Beaver (1981), Kjemperud (1982), De Wolf (1982), Krammer and Lange-Bertalot (1986-1991), Denys (1991a, b), Vos and De Wolf (1988, 1993), Van Dam et al. (1994), and Witkowski et al. (2000).

Diatom assemblage zones were delimited with a broken-stick model of the distribution of variance (Bennett, 1996), implemented in Psimpoll 4.10. Subzones were defined by stratigraphically constrained cluster analysis based on squared Euclidian dissimilarity (CONISS, Grim, 1987). A total dispersion cut-off of 0.5 was used for the definition of the subzones. All statistical analyses were carried out on a diatom relative abundance matrix of those taxa attaining a frequency of $2 \%$ in at least one sample.

\section{RESULTS}

\section{Stratigraphy and Sedimentology}

The three cores studied perforated the entire Holocene sequence, reaching the granitic basement (Fig. 2). Core TR1 is composed of $4.30 \mathrm{~m}$ of organic muds and peats with very thin intercalations of wellsorted sands that correspond to lacustrine sediments intercalated with aeolian beds. Core TR2 perforated $10.5 \mathrm{~m}$ of a series basically made up of well-sorted and rounded bioclastic sands, although the base consists of alluvial gravelly sands passing upwards to $0.50 \mathrm{~m}$ of organic muds and thin intercalations of aeolian sands. Core TR3, located close to the outlet, is composed of $2.90 \mathrm{~m}$ of aeolian sands.

More detailed sedimentological analyses of the three cores, mainly based on granulometric and microscopic inspections of the fraction $>63 \square \mathrm{m}$, allowed the definition of 11 facies associations (Table 1).

All these facies associations are irregularly distributed throughout the three cores (Fig. 2). TR1 shows, from bottom to top (FA1: 420-390 cm depth; FA2: 390-350 cm; FA3: 350-260 cm; FA4: 260$230 \mathrm{~cm}$; FA5: $230-170 \mathrm{~cm}$; FA6: 170-35 cm; FA7: $35-0 \mathrm{~cm})$, a fine-to-coarse sequence that represents the infilling of a coastal water body with sandbarrier inputs at times of increased storminess. Swamp conditions developed under a poor drainage system at the beginning of the lacustrine system. This first stage then gave rise to a small but welldeveloped shallow lake. Some levels, enriched with aeolian sand grains (particularly at 260-230 cm), indicate increased storm activity. The facies associations at the top of the core have indications of inputs by tractive currents, reflecting the increasing agricultural activity and conducive to the present phase of infilling of the coastal wetland.

The facies associations in core TR2 (FA1: 1020$995 \mathrm{~cm}$ depth; FA8: $995-981$ and 945-910 cm; FA8b: 981-945 cm; FA9: 910-30 cm; FA10: 30-0 $\mathrm{cm}$ ) are mainly composed of aeolian sands with a bioclastic content of $10-15 \%$. These deposits overlay an organic mud layer, indicating the inland progradation of the sand barrier, which migrated over an irregular rocky ramp.

The facies associations in core TR3 (FA9: 290$60 \mathrm{~cm}$; FA10: $60-0 \mathrm{~cm}$ ) show aeolian sands directly resting over the regolith.

In summary, the described facies can be grouped into four sedimentary units as follows.

Unit 1 (episodic stream and flash flood deposits). This unit includes FA1 and always appears at the base of the sedimentary record, representing a stage of erosion of the regolith and diffuse drainage of the basin.

Unit 2 (palustrine, back-barrier swamp deposits). This sedimentary unit includes FA2, FA3, FA4, FA7, FA8, and FA8b. It represents the commencement of poor drainage conditions and the retention of water in the back barrier, in the context of a low rate rising sea level.

Unit 3 (lacustrine deposits). This unit is characterized by FA5 and FA6, corresponding to the development of a shallow freshwater lake. 


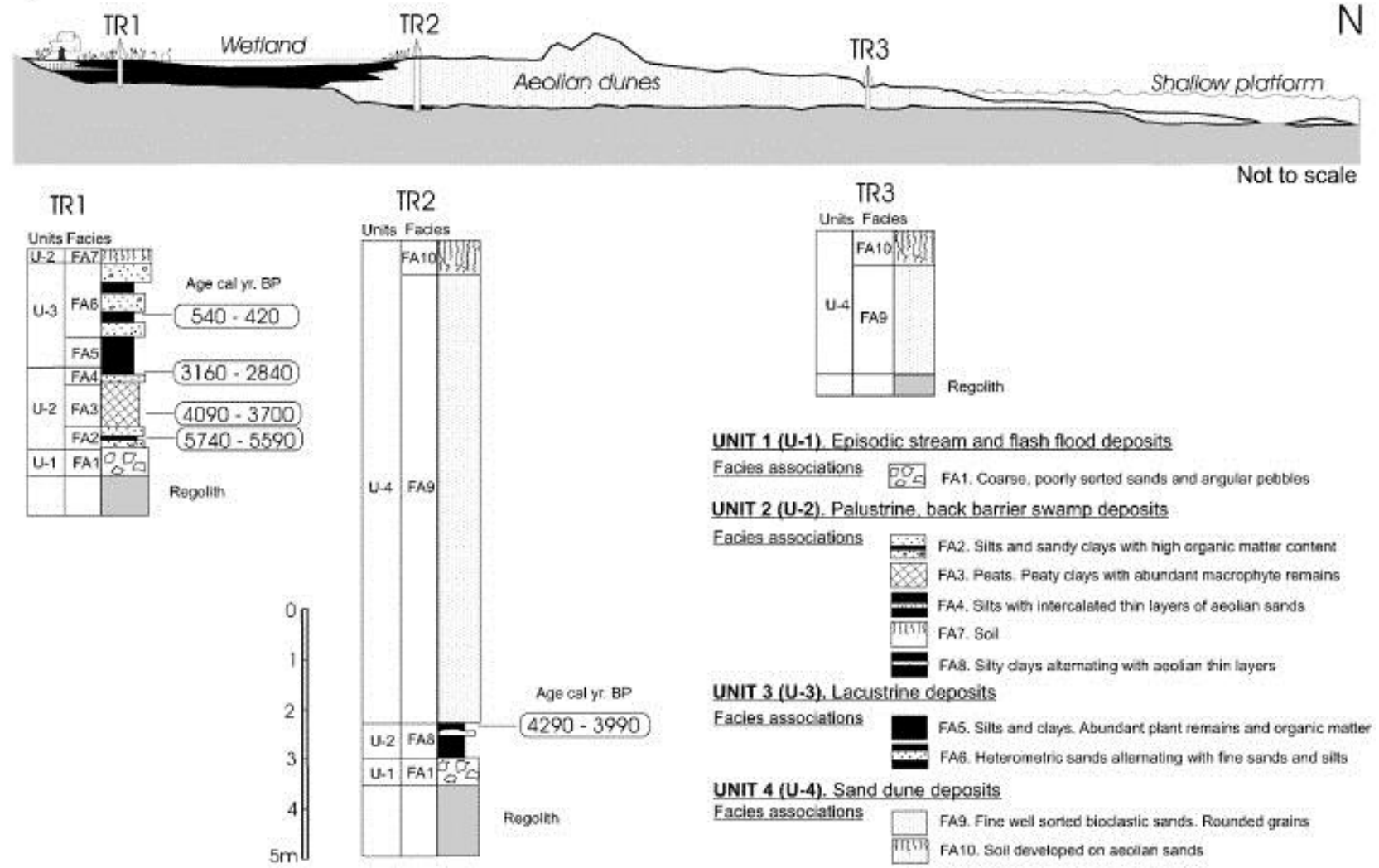

Fig. 2. Sedimentology and north-to-south relationships of the studied cores relative to heights above mean sea level. Dates are calibrated ranges.

Unit 4 (sand-dune deposits). This last sedimentary unit is composed of FA9 and FA10 and represents the development of the entire dune complex in the beach-barrier system. The construction of this system was strongly conditioned by the sediment input and the continuous sea-level rise.

\section{Chronology and Sedimentation Rates}

Four samples from core TR1 were dated by the standard ${ }^{14} \mathrm{C}$ radiometric technique to produce a chronology for the last c. 5,700 cal yr. Only one sample from core TR2 with a sufficient carbon content could be dated (Table 2).

Dates throughout core TR1 were linearly interpolated between adjacent radiocarbon dates and the undated core top, which was assumed to have zero age. Plotting the radiocarbon ages versus core depths (Fig. 3) gives an average

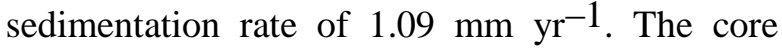
sedimentation rates yield fairly constant values in the bottom and middle parts of the core (ranging between $0.28 \mathrm{~mm} \mathrm{yr}^{-1}$ and $0.45 \mathrm{~mm} \mathrm{yr}^{-1}$ at $c$. 5,700-3,900 cal yr BP and c. 3,000-480 cal yr $\mathrm{BP}$, respectively) with the exception of the interval at 330-235 cm (c. 3,900-3,000 cal yr $\mathrm{BP})$, where the sedimentation rate increases to $1.03 \mathrm{~mm} \mathrm{yr}^{-1}$. The top of the core (c. $480 \mathrm{cal} \mathrm{yr}$ $\mathrm{BP}$ to the present) has a maximum sedimentation rate of $2.60 \mathrm{~mm} \mathrm{yr}^{-1}$.

Assuming the same sedimentation rates for both TR1 and TR2, we have estimated the age of the base of Unit 2 in core TR2 to be 5,700 cal yr BP. This estimate is based on the proximity of both sites and their facies similarities, and gives the same age as was obtained by radiocarbon dating at the bottom of Unit 2 in TR1. 
Table 1.

Facies associations recognized in the Traba sedimentary infill

\begin{tabular}{|c|c|c|c|}
\hline $\begin{array}{l}\text { Facies } \\
\text { association }\end{array}$ & Lithology & Fossil content & $\begin{array}{l}\text { Depositional } \\
\text { environment }\end{array}$ \\
\hline FA1 & $\begin{array}{l}\text { Coarse, poorly sorted sands and angular } \\
\text { clasts. Tractive transport of the regolith } \\
\text { originated from the weathering of the } \\
\text { granitic basement }\end{array}$ & - & $\begin{array}{l}\text { Episodic high-energy } \\
\text { stream deposits }\end{array}$ \\
\hline FA2 & $\begin{array}{l}\text { Silts and sandy clays alternating with thin } \\
\text { layers of heterometric sands. High organic } \\
\text { matter content }\end{array}$ & - & $\begin{array}{l}\text { Swamp zones with } \\
\text { episodic distal stream } \\
\text { deposits }\end{array}$ \\
\hline FA3 & $\begin{array}{l}\text { Peats and peaty clays with scattered } \\
\text { carbonaceous particles. Very thin layers of } \\
\text { aeolian sands intercalated }\end{array}$ & Macrophyte remains & $\begin{array}{l}\text { Swamps, shallow } \\
\text { lacustrine }\end{array}$ \\
\hline FA4 & $\begin{array}{l}\text { Silts with intercalated thin layers of sands. } \\
\text { Sands are composed of rounded quartz } \\
\text { grains }\end{array}$ & $\begin{array}{l}\text { Macrophyte remains and } \\
\text { diatoms }\end{array}$ & Interdune ponds \\
\hline FA5 & $\begin{array}{l}\text { Silts and clays with high organic matter } \\
\text { content. Scattered rounded sand grains and } \\
\text { carbonaceous particles }\end{array}$ & $\begin{array}{l}\text { Plant remains (cuticles, seeds, } \\
\text { charophyte oogonia). } \\
\text { Abundant diatoms }\end{array}$ & $\begin{array}{l}\text { Lacustrine with minor } \\
\text { aeolian influx into the } \\
\text { lake }\end{array}$ \\
\hline FA6 & $\begin{array}{l}\text { Micaceous heterometric sands and pebbles. } \\
\text { Coarser sand layers alternate with fine } \\
\text { sands. Angular grains and heavy minerals. } \\
\text { Organic matter }\end{array}$ & Diatoms. Plant remains & $\begin{array}{l}\text { Lacustrine-palustrine } \\
\text { affected by some } \\
\text { sporadic stream activity }\end{array}$ \\
\hline FA7 & $\begin{array}{l}\text { Fine micaceous sands with high organic } \\
\text { content }\end{array}$ & $\begin{array}{l}\text { Macrophyte and diatom } \\
\text { remains }\end{array}$ & Well-developed soil \\
\hline \multirow[t]{2}{*}{ FA8 } & $\begin{array}{l}\text { Alternation of centimetric layers of well- } \\
\text { rounded bioclastic fine sands with silty } \\
\text { clays highly enriched in organic matter }\end{array}$ & Diatoms & Back-barrier ponds \\
\hline & $\begin{array}{l}\text { FA8b includes centimetric layers of } \\
\text { heterometric fine sands and scarce pebbles }\end{array}$ & & $\begin{array}{l}\text { Back-barrier ponds } \\
\text { subject to intermittent } \\
\text { stream flows }\end{array}$ \\
\hline FA9 & $\begin{array}{l}\text { Fine homometric bioclastic sands. Grains } \\
\text { show a rounded to well-rounded } \\
\text { morphology, with smooth and frosted } \\
\text { surfaces }\end{array}$ & $\begin{array}{l}\text { Fragmented bioclasts. } \\
\text { Gastropods, echinoid spines } \\
\text { and plates, bivalves and } \\
\text { foraminifera }\end{array}$ & $\begin{array}{l}\text { Aeolian sand-dune } \\
\text { system }\end{array}$ \\
\hline FA10 & $\begin{array}{l}\text { Homometric aeolian sands with high } \\
\text { organic content }\end{array}$ & Plant remains & $\begin{array}{l}\text { Soil developed over the } \\
\text { sand-dune system }\end{array}$ \\
\hline
\end{tabular}

\section{Diatom Stratigraphy}

The three cores were checked for diatom content, but preservation was very variable. Core TR1 gave the most complete diatom record, consisting of 178 taxa. However, some parts of the core showed only valve fragments, making quantitative estimations impossible. Other stretches were barren of diatoms. Core TR2 showed diatoms (50 taxa) only in a short $50 \mathrm{~cm}$ interval of organic muds, and the rest of the core was barren. Core TR3, consisting almost entirely of aeolian sands, was devoid of diatoms. Diagrams of the relative abundances of those taxa reaching a frequency of $2 \%$ in at least one sample in cores TR1 and TR2 are shown in Figures 4 and 6, respectively. Facies associations and sedimentary units are also indicated in the figures. The diatoms have been grouped by their salinity and habitat tolerances, according to the criteria of Vos and De 
Table 2.

Radiocarbon and calibrated calendar ages for cores TR1 and TR2

\begin{tabular}{lllllll}
\hline $\begin{array}{l}\text { Laboratory } \\
\text { number }\end{array}$ & Core & $\begin{array}{l}\text { Depth } \\
(\mathrm{cm})\end{array}$ & $\begin{array}{l}\text { Height relative } \\
\text { to msl }(\mathrm{cm})\end{array}$ & $\begin{array}{l}\delta^{13} \mathrm{C} \\
(\%)\end{array}$ & $\begin{array}{l}\text { Measured radiocarbon } \\
\text { age }(\mathrm{yr} \mathrm{BP} \pm 1 \sigma)\end{array}$ & $\begin{array}{l}\text { Calibrated age }(2 \sigma \\
\text { calibrated results })\end{array}$ \\
\hline$\beta-165860$ & TR1 & 380 & 50 & -25.0 & $4920+/-50$ & $5740-5590$ \\
$\beta-165861$ & TR1 & 330 & 100 & -25.0 & $3600+/-70$ & $4090-3700$ \\
$\beta-177715$ & TR1 & $235-240$ & $190-195$ & -25.0 & $2860+/-60$ & $3160-2840$ \\
$\beta-177714$ & TR1 & 125 & 305 & -25.0 & $430+/-60$ & $540-420$ \\
$\beta-165862$ & TR2 & 940 & -440 & -25.0 & $3780+/-50$ & $4290-3990$ \\
\hline
\end{tabular}

Wolf (1993), as well as following the halobian scheme of Hustedt (1957) and by their pH affinities (Hustedt,1937-39; 1957) (Figs. 5 and 7). Three diatom assemblage zones (DAZs) have been distinguished for core TR1 and one for core TR2.

\section{Core TRl}

DAZ TRI-I: $60 \mathrm{~cm}$ and $175-200 \mathrm{~cm}$ above m. s. 1.; interpolated age c. 5,500 cal yr BP and c. 3,2002,900 cal $\mathrm{yr} \mathrm{BP}$, respectively. This zone is characterized by the dominance of freshwater and brackish/freshwater tychoplanktonic diatoms (mainly Stauroforma exiguiformis Flower, Jones \& Round and Staurosira construens f. subsalina (Hustedt) Bukhtiyarova), which always represent about $50-90 \%$ of the total assemblage. These values are typical of a non-tidal lagoon environment in the classification of Vos and De Wolf, (1993). The dominance of diatoms from the Fragilaria complex (made up in Traba's sedimentary record of Fragilaria sensu stricto, Fragilariforma, Staurosira, Pseudostaurosira and Stauroforma) also points to environmental instability (Stabell, 1985), probably because of frequent changes in salinity. This is corroborated by the mixture in this zone of diatoms with different salinity optima, such as the halophobous Stauroforma exiguiformis and the oligohalobous halophilous Staurosira construens f. subsalina. This phenomenon indicates seasonal fluctuations in salinity or the influence of sea spray. The tychoplanktonic character of these diatoms suggests the development of a shallow environment with open waters.

DAZ TRI-II: 200-400 cm above m. s. 1.; interpolated age $c$. 2,900-150 cal yr BP. Freshwater epiphytic diatoms are the main component of this zone, ranging in abundance from $50 \%$ to $75 \%$. The dominant species is Achnanthidium minutissimum (Kützing) Czarnecki. This assemblage is typical of a non-tidal lagoon with important macrophytic development in the classification of Vos and De Wolf (1993). However, this zone shows some variations that allow the distinction of three different subzones. In subzone TR1-IIa (c. 2,900-2,500 cal yr $\mathrm{BP})$, the freshwater epipelon, mainly made up of Brachysira vitrea (Grunow) Ross in Hartley, constitutes the subdominant group of the whole assemblage. Subzone TR1-IIb (c. 2,500-400 cal yr BP) represents the baseline wetland conditions, with

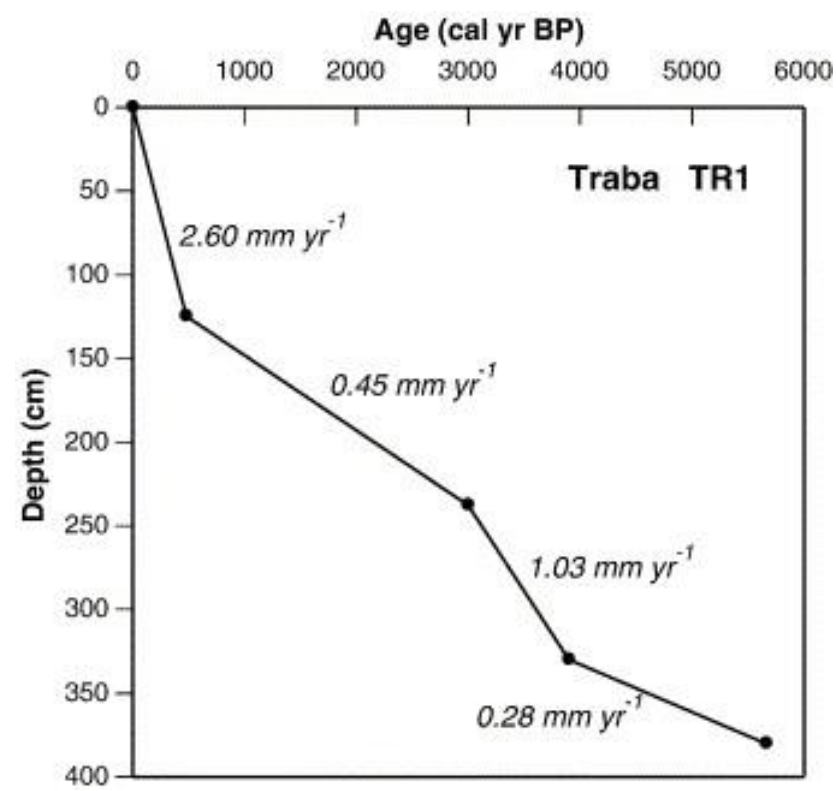

Fig. 3.

Sedimentation rate curve for core TR1. 


\section{Traba TR1 (4.30 m above m. s. I.)}

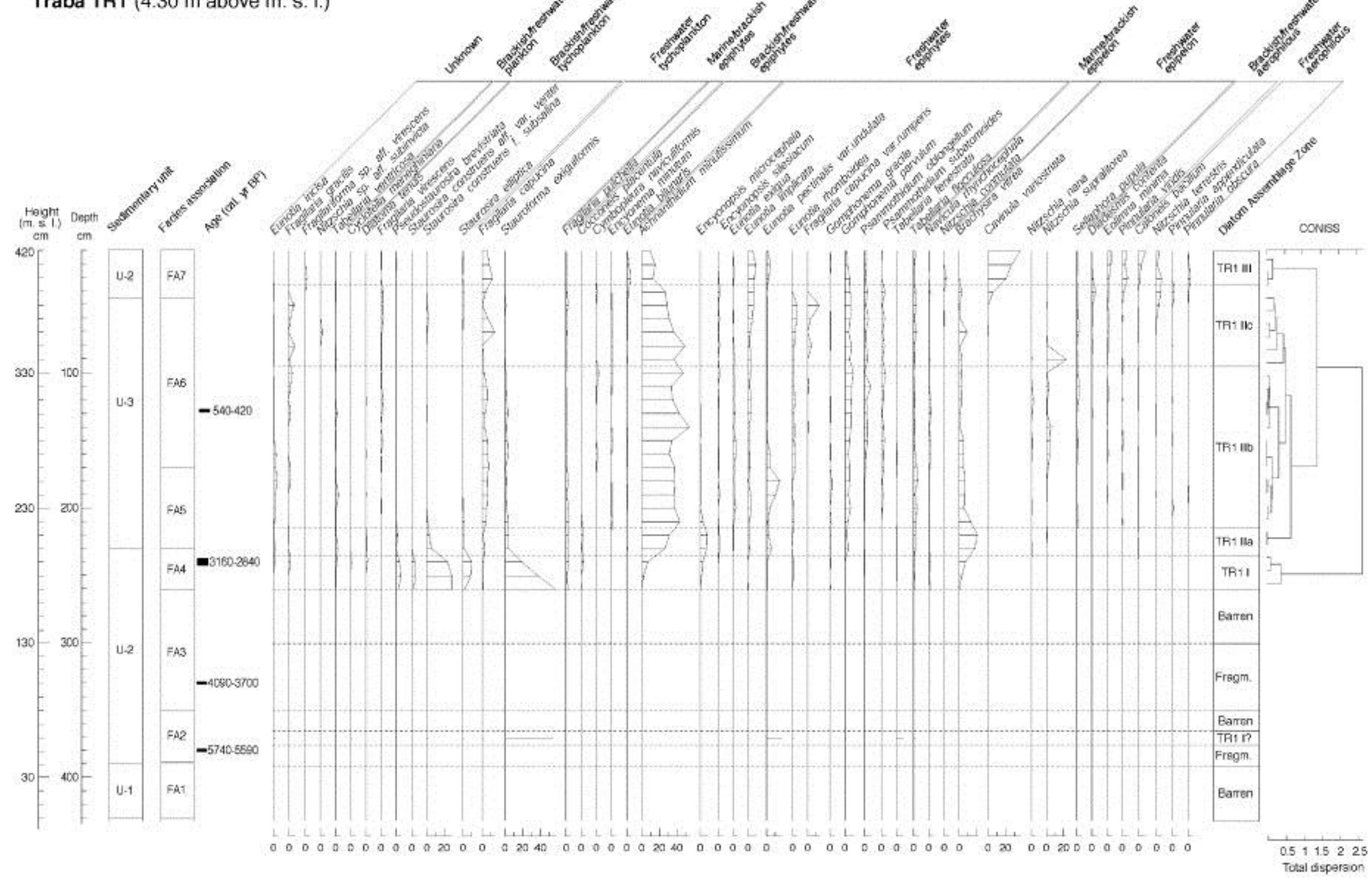

Fig. 4. Diatom percentage diagram for selected taxa ( $\geq 2 \%$ abundance in at least one sample) from TR1. Ecological groups according to Vos and De Wolf (1993). 
Traba TR1 (4.30 m above m. s. I.)

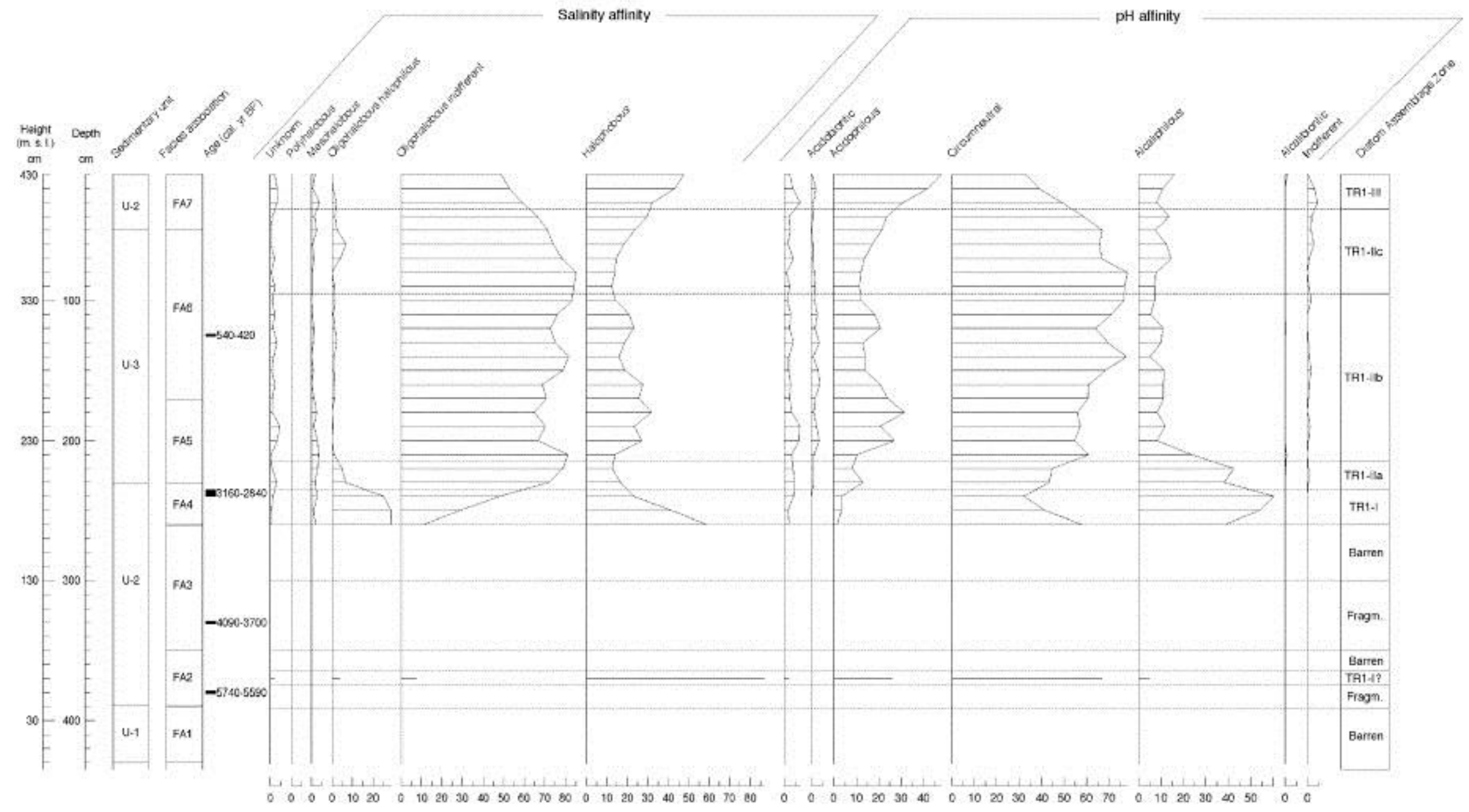

Fig. 5. Percentage diagram for diatom taxa from TR1 grouped according to their salinity and $\mathrm{pH}$ affinities. 


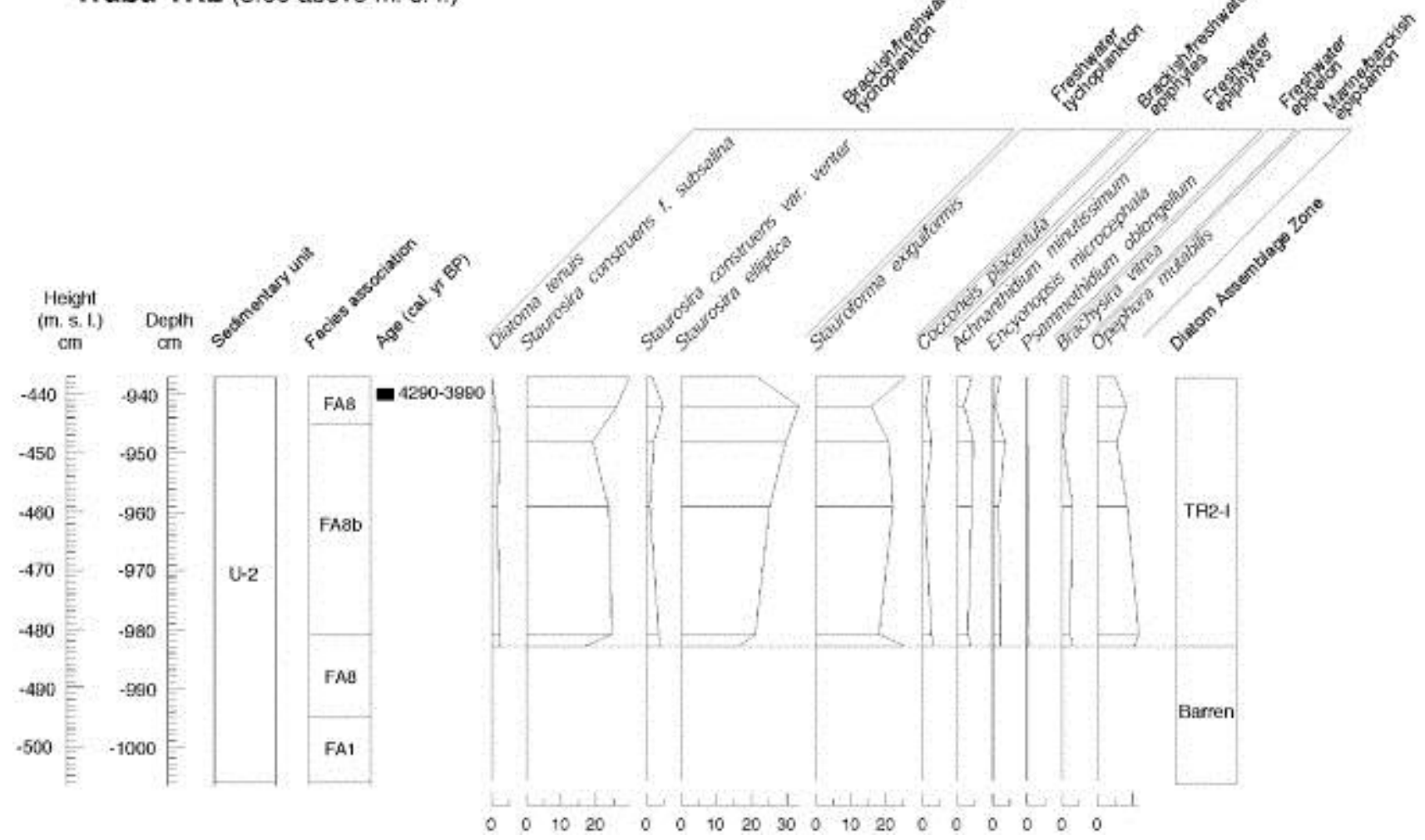

Fig. 6. Diatom percentage diagram for selected taxa ( $\geq 2 \%$ abundance in at least one sample) from TR2. Ecological groups according to Vos and De Wolf (1993).

extensive macrophytic development, as indicated by the high values for the freshwater epiphytic component, which always has an abundance of more than $60 \%$. A probable greater sediment availability is reflected in subzone TR1-IIc (c. 400-150 cal yr $\mathrm{BP})$, where a new peak of the subdominant freshwater epipelon is recorded, mainly represented by Sellaphora pupula (Kützing) Mereschkowksy, Cavinula variostriata (Krasske) Mann and Stickle and B. vitrea.

DAZ TRI-III: $400-430 \mathrm{~cm}$ above m. s. 1.; interpolated age $c .150 \mathrm{cal}$ yr $\mathrm{BP}-$ present. The most significant trend in this zone is the reduction in freshwater epiphytic diatoms in favour of the freshwater epipelon (mainly represented by Cavinula variostriata) and both freshwater and brackish/freshwater aerophilic diatoms (such as Diadesmis contenta (Grunow ex Van Heurck) Mann, Eolimna minima (Grunow) LangeBerlalot, Caloneis bacillum (Grunow) Cleve, and Pinnularia viridis (Nitzsch) Ehrenberg). Both the epipelic and aerophilic character of the dominant diatoms indicate strong sedimentation conditions and at least seasonally based desiccation events reflecting the progressive terrestrialization of the water-body margins. The halophobous nature of these diatoms also indicates water freshening at this site, compared with the dominance of oligohalobous-indifferent diatoms in the previous zone.

\section{Core TR2}

DAZ TR2-1: 437 to $483 \mathrm{~cm}$ below m. s. 1.; interpolated age c. 5,700-4,000 cal yr BP. This single zone is characterized by the codominance of tychoplanktonic diatoms of both brackish/freshwater (mainly Staurosira construens f. subsalina and Staurosira elliptica (Schumann) Williams \& Round) and freshwater character (Stauroforma exiguiformis). Marine/brackish epipsammic diatoms, consisting of Opehora mutabilis (Grunow) Sabbe \& Vyverman, constitute the subdominant group in this assemblage. This zone shows a strong resemblance to the base of zone TR1-I of the previous core but is slightly younger in age. As in TR1-I, the diatom assemblage suggests the development of swamp conditions that are subject to environmental instability. The main difference between TR1-I and 


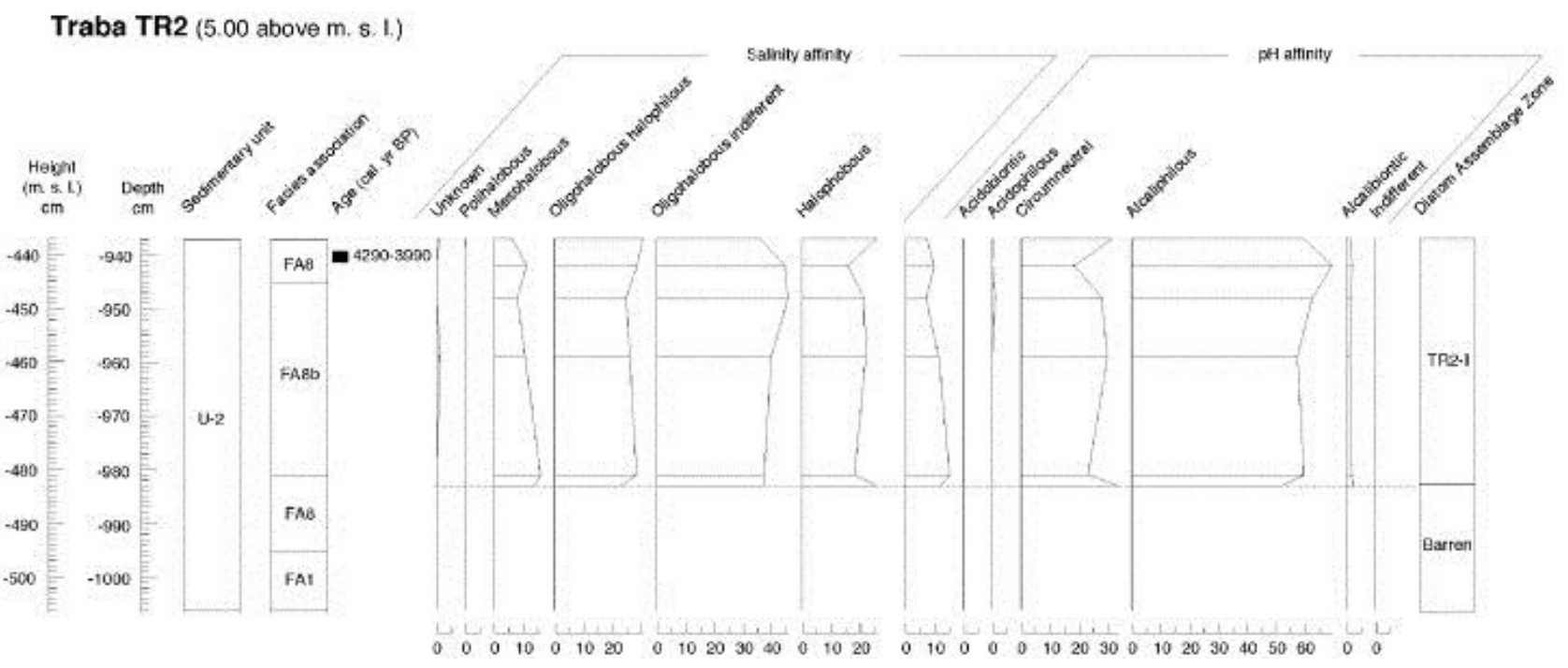

Fig. 7. Percentage diagram for diatom taxa from TR2 grouped according to their salinity and $\mathrm{pH}$ affinities.

TR2-I is the importance of the marine/brackish epipsammic component in the latter, which could

\section{PALAEOENVIRONMENTAL RECONSTRUCTION}

Five main phases in the evolution of the Traba coastal wetland can be distinguished according to the lithofacies and changes in the diatom assemblages, based as well as on correlations among the three cores studied (Fig. 8).

Phase $0(?-c .5,700$ cal yr BP). The sedimentary record of Traba starts before c. 5,700 cal yr BP with the development of alluvial conditions. During this phase, episodic high-energy streams ran over a poorly drained irregular rocky basement, weathering the regolith.

Phase 1 (c. 5,700-4,000 cal yr BP). This period marks the start of lacustrine-palustrine sedimentation and therefore the onset of the Traba coastal wetland. The diatom assemblages of this phase, consisting predominantly of species from the Fragilaria complex, are typical of pioneering diatom communities, colonizing newly formed lacustrine habitats (Reed et al., 1999) in both TR1 and TR2 positions. In the latter, closer to the coastline, marine/brackish epipsammic diatoms constitute a subdominant group. This indicates that the beachbarrier was still very incipient and permeable reflect higher salinitites, either by permeating sea water, extreme high waters or sea spray.

enough to allow the development of more saline conditions, at least intermittently, at this site. The Fragilaria complex-dominated diatom assemblage is consistent with a shallow pond, the salinity of which did not exceed 1,500 $\mathrm{mg} \mathrm{Cl} \mathrm{L}^{-1}$ (Vos and de Wolf, 1994). Time averaging of the diatom record results in a diatom assemblage that is a mixture of diatoms of different salinity optima such as the halophobous and the oligohalobous halophilous taxa. This and the very broad ecological tolerances of species of the Fragilaria complex (Stabell, 1985; Reed et al., 1999) suggest that this period was marked by environmental instability in a shallow water body with little connection to the sea. Sediment influx into the lacustrine system was at its minimum point $\left(0.28 \mathrm{~mm} \mathrm{yr}^{-1}\right)$ in the whole history of the wetland.

Phase 2 (c. 4,000-3,200 cal yr BP). There is a gap in the diatom record of the three studied cores during this interval. Lithofacies analysis of the TR1 core shows the development of mostly palustrine conditions during this phase. At the same time and, until the present, TR2 was subjected to aeolian sand deposition, with no further development of a lacustrine stage. The landward movement of the sand barrier during this phase is indicated by the 

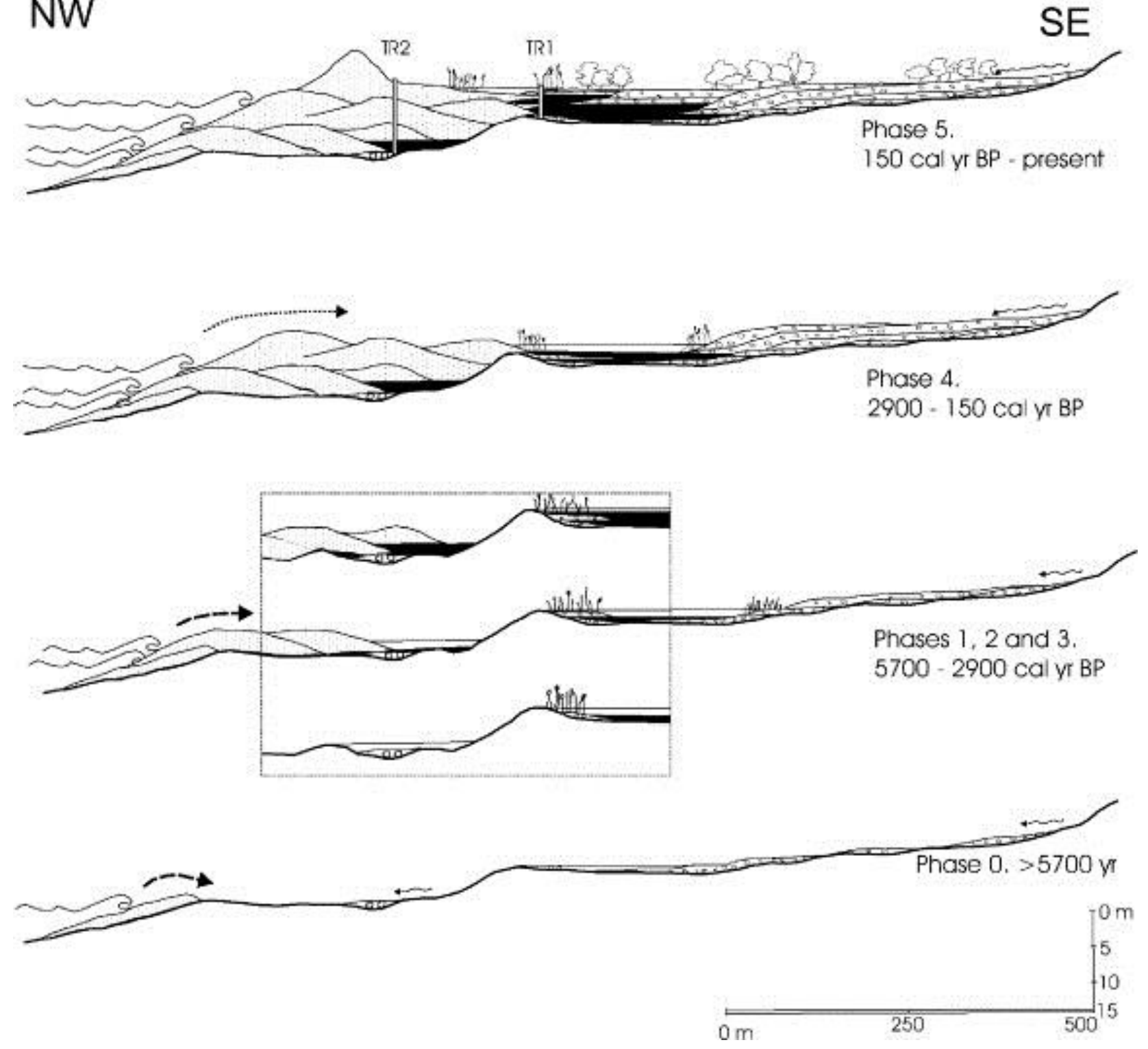

Fig. 8. Evolutionary model for Traba coastal wetland since its origin $5700 \mathrm{cal}$ yr BP.

presence of scattered aeolian sand layers. This migration of the barrier has also been detected previously and dated at 3,370 $\pm 90 \mathrm{yr}$ BP (Devoy et al., 1996).

Phase 3 (c. 3,200-2,900 cal yr BP). In this time interval, the particular environmental conditions of the lacustrine origin of the basin were re-established at TR1, with a pioneering diatom community mainly made up of species of the Fragilaria complex, which colonized a waterlogged lowland. The dune sand barrier was consolidated in the TR2 position at this time. The data suggest that from phase 1 to phase $3(5,700-2,900 \mathrm{yr}$ cal $\mathrm{BP})$, the lacustrine system was poorly developed in the basin and was subject to high environmental instability, in part associated with changes in the drainage system. A complex of shallow ponds probably developed through phases 1 to 3 , with their changing positions related to the migration of a still diffuse drainage network. This would explain the periods of pond development (phases 1 and 3) and the stages of desiccation that explain the absence of diatoms (phase 2) at the TR1 site. Although the salinity was never high, the predominant oligosaline conditions indicated by the dominance of oligohalobous taxa point to some barrier permeability during this time interval. Although circumneutrality must have been the normal condition of the water body throughout its whole history, the dominance of the alkaliphilic species of the Fragilaria complex suggests a higher $\mathrm{pH}$ in this phase. 
Phase 4 (c. 2,900-150 cal yr BP). More stable conditions seem to have occurred during this phase compared with those of the previous stages. The Fragilaria complex-dominated diatom assemblage was substituted by a community dominated by freshwater epiphytes, mainly Achnanthidium minutissimum. This species represents the prevalence of freshwater conditions with extensive macrophytic development but it has also been reported to be an indicator of increased infilling in wetlands behind a sand barrier (Earle and Duthie, 1986). However, the transition from Phase 3 to this condition was not abrupt, as indicated by the codominance of freshwater epipelic diatoms such as Brachysira vitrea during the interval c. 2,900-2,500 cal yr BP (diatom subzone TR1-IIa). The epipelic character of this taxa probably suggests a time when vegetation colonization at the bottom of the water body was still not complete. The freshwater conditions and the extensive macrophytic development that supported epiphytic diatom communities from c. 2,500-400 cal yr BP was again subjected to change during the interval $c .400-150$ cal yr BP (diatom subzone TR1-IIc). Although a net freshening trend is indicated by the increasing abundance of halophobous taxa, oligohalobous halophilous diatoms also show a minor peak. The development of halophilous taxa is stimulated when slightly saline conditions exist, so the general trend to a more freshwater environment must have been interrupted by a minor saline intrusion that never attained the unstable regime such as developed during phases 1 to 3 . The clear increasing trend in acidophilous taxa in the period c. 400-150 cal yr BP points to an acidification associated with the development of more palustrine conditions. These are coincident with the highest sedimentation rate detected for the whole sequence $\left(2.60 \mathrm{~mm} \mathrm{yr}^{-1}\right)$.

Phase 5 (c. 150 cal yr BP-present). This period encompasses the evolution of the Traba coastal wetland during the 19th and 20th centuries to the present. There is a sharp change in the diatom assemblages, which are now dominated by freshwater epipelic taxa. The swamp encroachment that started at the end of phase 4 has been the most outstanding feature for about the last 200 years, reflecting an increased continental sediment influx into the wetland. This encroachment could have been intensified by increased nutrients introduced by agriculture and farming, stimulating reed growth in the marginal areas. Intermittent desiccation conditions, probably because of stational minor lake level variations, as observed today, are indicated by minor peaks in aerophilous diatoms. The decomposition of the increased macrophytic organic matter related to the palustrine conditions could explain the continuing acidification trend in the most recent part of the wetland's history.

\section{DISCUSSION}

Existing Postglacial sea-level curves for the western Iberian Peninsula (Dias et al., 2000) still lack a good set of precise sea-level index points for most of the Holocene. The salinity tolerances of the oligohalobous-indifferent taxa that dominate the diatom assemblage found at the base of core TR2 (4.85 m below m. s. 1.) indicate that, at that time, sea level did not reach the basin but was very close to it. If the present-day spring tidal range $(4.40 \mathrm{~m})$ has not changed significantly in the region for the last 6,000 $\mathrm{yr}$, we can establish that the sea-level postion was at least $7 \mathrm{~m}$ below m. s. 1 . at $5,700 \mathrm{cal}$ yr BP. Uncertainties arising from sediment compaction can be disregarded in Traba because of the nearness to the rocky basement (just $35 \mathrm{~cm}$ ) of the stratigraphic level used to establish this sea-level.

The origin of the Traba coastal wetland can be established at 5,700 cal yr BP, which is coetaneous with the establishment of stable sand barriers in the Atlantic sector of the Iberian Peninsula coincident with the mid-Holocene deceleration of sea-level rise (Freitas et al., 2002). The informal use of the term "lagoon" for any coastal water body, either partly or wholly separated from the sea by a strip of land, has posed problems for the correct definition of these coastal systems (Cooper, 1994; Davis and Fitzgerald, 2004). Under normal circumstances, its current height, which is clearly above the highest high water, prevents the Traba wetland from being considered a lagoon by the more restrictive definition of Lankford (1977). However, it cannot be ignored that Traba could have behaved as a coastal lagoon for some time in its history. Portuguese coastal lagoons, for instance, alternated between periods of complete isolation from the sea and periods when barrier breaching allowed connection and exchanges with the ocean (Freitas and Andrade, 
2005). It has also been suggested that the maximum Holocene sea level at the Iberian Peninsula reached a position above the present-day level (Clark et al., 1978; Zazo et al., 1996), thus making the entrance of the sea to the Traba basin feasible, at least at that time. However, diatom data show that freshwater or only slightly brackish water conditions (always well below 5\%) have dominated since its origin at approximately 5,700 cal yr BP. The sea level never clearly surpassed the basement threshold, so the inland water body always remained with no or minimal connection to the sea. Therefore, Traba was never flooded by the sea because it lacked a past open bay stage, as has been recorded elsewhere on the Iberian Peninsula for similar coastal systems (Cearreta et al., 2003; Freitas et al., 2002). Topographic inheritance was the major forcing factor that defined the Traba wetland more as a coastal lake than as a "closed lagoon system" (as previously defined by Vilas and Rolán, 1985) for its whole history. Observations made during intensive bird monitoring work in the Traba wetland for the last 30 years have also indicated that, even during the most extreme storm event recorded (December $\left.13^{\text {th }}, 1978\right)$, the sea never penetrated the wetland via an outlet to the sea or by overwashing (J. L. Rabuñal, pers. comm.). Only when the outlet was artificially excavated down to the basement, in March 1992, did the high tide affect a small part of the wetland close to the outlet.

Despite the minor connection to the sea throughout most of its history, Traba currently faces an intensified rate of sea-level rise under the global warming scenario (Overpeck et al., 2006). Therefore, we can hypothesize that this, together with the reduced sediment supply resulting from the extensive reservoir construction in the Galician hinterland during the last 50 years, may have increased the permeability of the Traba's sandbarrier system and other sand-barrier systems of the region. This seems to be the case in some coastal wetlands in Galicia (Santos et al., 2001), a region where changes in sediment supply and rising sea level have caused important coastal erosive effects in some areas (Vilas et al., 1995; Alonso et al., 2000; Delgado et al., 2002; Lorenzo et al., 2003). There is also evidence that the present-day negative accretionary status of some of the neighbouring Portuguese coastal wetlands will not keep pace with the current rapid sea-level rise (Arnaud-Fassetta et al., 2006). Although Traba never behaved as a coastal lagoon sensu stricto, the model of Nichols (1989) gives an appropriate framework with which to examine this interdependence between sediment supply and sea-level rise because of Traba's contiguity with the sea. The same model has also been applied successfully to coastal systems elsewhere, that are not strictly defined as lagoons (Spencer et al., 1998).

Nichols (1989) and Nichols and Boon (1994) classified coastal lagoons as "deficit lagoons" when the effects of sea-level rise predominate over sediment supply; "surplus lagoons" when sediment infill outpaces sea-level rise, resulting in smaller water bodies; and "equilibrium lagoons" when the increase in the water body because of sea-level rise equals the rate of sediment infill. The model has profound implications for any management practices that are carried out on aquatic coastal systems, which must consider the long-term evolution of the system to achieve a correct assessment (Smol, 1992). This is indeed the case with the Traba coastal wetland, the future evolution of which will depend on the relative importance of different driving factors, mainly sea-level and sediment supply changes.

The relative sea-level rise on the Galician coast has been estimated at $2.55 \mathrm{~mm} \mathrm{yr}^{-1}$ for the last $55 \mathrm{yr}$, according to tide gauge records (Lorenzo et al., in press). On the other hand, according to our data, the sedimentation rate for approximately the last $450 \mathrm{yr}$ in the Traba wetland is estimated at $2.60 \mathrm{~mm} \mathrm{yr}^{-1}$, a result that fits very close to the equilibrium line of Nichols and Boon (1994). Encroachment in the marginal areas of the Traba water body began around $1800 \mathrm{AD}$ (DAZ TR1-III; c. 150 cal yr BP) and has not decelerated in recent times. On the contrary, this infilling has intensified dramatically from 1992 to the present, when reeds started to rapidly colonize the northern shore because of changes in land use (J. L. Rabuñal, pers. comm.). The present-day accelerated deforestation by recurrent forest fires each summer is also contributing to this intensified continental sediment supply to the basin. Accordingly, the predicted sealevel rise of $0.09-0.88 \mathrm{~m}$ for the $21^{\text {st }}$ century (IPCC, 2001) is likely to have little effect on the short-term 
evolution of the system. The intensified anthropogenic sediment input is currently the main forcing factor governing the final fate of the wetland. Any management practice directed to preserving the ecosystem as it was for most of its history should first address this positive accretionary status, with the current rapid sea-level rise playing a secondary role in the short term. This resilience of the wetland to rapid sea-level rise will probably persist until the basement threshold is surpassed by mean high water in the long term.

Although storms are considered major agents in the evolution of barrier coasts (Andrade et al., 2004), they seem to have had little effect on the last 2,900 yr of Traba's history, with one exception. The increase in saline diatom taxa at the end of phase 4 (DAZ TR1-IIc) can tentatively be dated to approximately 270-190 cal yr BP (around 16801760 AD), reflecting the increased permeability of a previously consolidated sand barrier. An intensification of storminess at this time, or even the effects of the 1755 AD tsunami of Lisbon, could be invoked to explain this short-term more permeable state of the sand barrier. However, the diatom assemblage composition indicates that intensified storminess in the region must have played a more prominent role in the first half of the life of the wetland. The change from the swampy unstable conditions recorded between 5,700 and 2,900 cal yr $\mathrm{BP}$ (phases 1 to 3 ), characterized by an increase in the permeability of the sand barrier, to the more stable lacustrine situation starting at 2,900 cal yr BP (phase 4), coincides with the onset of the Subatlantic period. At this time, a shift from a storm-dominated regime to low-energy conditions took place on the Galician continental shelf (González-Álvarez, et al., 2005). This situation must have impeded the establishment of a stable sand-barrier system enclosing a shallow water body behind it, as developed after 2,900 cal yr BP.

Excessive man-induced sedimentation, and not sealevel rise, is currently the main forcing factor in the evolution of the Traba coastal wetland. As a result of lake encroachment, several threatened bird and plant species have declined in Traba during the last 30 years, being replaced by more generalistic species (J. L. Rabuñal and J. A. de Souza pers. comm.). Although man-modified wetlands can be restored to a condition similar to a former natural state for preserving its biodiversity, many have had a complex developmental history and there may be a variety of former natural states to choose from (Wheeler et al., 2002). However, this seems not to be the case of the Traba wetland. Palaeoenvironmental reconstruction shows that it has persisted as a coastal lake for about 2,900 years with minor naturally-induced changes. Palaeoenvironmental analyses can thus help to determine objectives of restoration to a desirable ecological condition in biodiversity conservation terms. Minimisation of sediment loads (including appropriate land use in the catchment) and vegetation clearance are palliative measures that would help functional life prolongation of the Traba coastal wetland. In the long run, dune degradation associated with rapid sea-level rise can also be a matter of concern and surveillance measures should already be undertaken.

\section{CONCLUSIONS}

The Traba coastal wetland, traditionally considered a lagoon system, instead behaved as a coastal lake with no or a minor connection to the sea throughout its 5,700-yr history. Diatom assemblage data allow the establishment of sea-level at least $7 \mathrm{~m}$ below present day m. s. 1. at 5,700 cal yr BP.

Changes in the relative importance of several interdependent controlling factors determined the evolution of the wetland since its origin. Its location on a basement high precluded an open connection to the sea despite its proximity. This topographic threshold was never surpassed by the sea level. Topography can thus be considered the major controlling factor in the evolution of this wetland.

The attenuation of the sea-level rise in the mid Holocene played a major role in the construction of the incipient sand barrier 5,700 cal yr BP. At this time, back-barrier water retention started, giving rise to a swampy environment that eventually evolved into a shallow lacustrine system with minimal connection to the sea. The increased storm activity on the Galician coast before the commencement of the Subatlantic period at 2,900 cal yr BP must have played a significant role in the permeability of the sand barrier enclosing the Traba wetland. Thereafter, 
only the storm events of 1680-1760 AD had a significant impact on the system.

Since at least the 19th century, more local forcing factors have determined the evolution of the system, including the increase in sediment supply resulting from changes in land use that is the key factor in its final fate. The palaeoenvironmental data obtained suggest that any future management practice directed to preserving the ecosystem as it was should first address the rapid infilling affecting the wetland, and secondly the effects of rapid sea-level rise.

\section{ACKNOWLEDGEMENTS}

This research was funded by project grants REN2000-0468 and CGL2004-0048BTE of the Spanish Ministry of Education. It is also a contribution to IGCP project no. 495 "Quaternary Land-Ocean Interactions: Driving Mechanisms and Coastal Responses". We thank Rosa Corbelle for her technical assistance during field and laboratory work. Birdwatchers José Luis Rabuñal and José Antonio de Souza, with their extensive knowledge of the wetland ecosystems of the Death Coast, provided invaluable data on the most recent natural and man-induced changes affecting the Traba coastal wetland. Manel Leira also provided very valuable discussions of a previous draft. We are grateful to two anonymous reviewers for their criticism and comments that improved the final manuscript.

\section{REFERENCES}

Alonso, A. and Pagés, J.L. 2000. El registro sedimentario del final del Cuaternario en el litoral noroeste de la Península Ibérica. Márgenes Cantábrico y Atlántico. Revista de la Sociedad Geológica de España, 13: 17 29.

Alonso, A., Lorenzo, F. and Pagés, J.L. 2000. Dinámica litoral y erosión en la ría de El Barquero: factores antrópicos y procesos naturales. Geogaceta, 28: 7-10.

Alonso, A., Pagés, J.L., López García, M.J. and Cearreta, A. 2003. Cronoestratigrafía de la transgresión holocena en el Golfo Ártabro (La Coruña, NO de España). In: Actas de la XI Reunión Nacional del Cuaternario (Ed G. Flor), pp. 33-38, Oviedo.
Anderson, N.J. 1995. Using the past to predict the future: lake sediments and the modelling of limnological disturbance. Ecological Modelling, 78: 149-172.

Anderson, N.J. and Vos, P. 1992. Learning from the past: diatoms as palaeoecological indicators of changes in marine environments. Netherlands Journal of Aquatic Ecology, 26: 19-30.

Andrade, C., Freitas, C., Moreno, J. and Craveiro, S.C. 2004. Stratigraphical evidence of Late Holocene barrier breaching and extreme storms in lagoonal sediments of Ria Formosa, Algarve, Portugal. Marine Geology, 210: 339-362.

Arnaud-Fassetta, G., Bertrand, F., Costa, S. and Davidson, R. 2006. The western lagoon marshes of the Ria Formosa (Southern Portugal): sedimentvegetation dynamics, long-term to short-term changes and perspective. Continental Shelf Research, 26: 363384.

Bao, R., Freitas, M.C. and Andrade, C. 1999. Separating eustatic from local environmental effects: a lateHolocene record of coastal change in Albufeira Lagoon, Portugal. The Holocene, 9: 341-352.

Beaver, J. 1981. Apparent Ecological Characteristics of Some Common Freshwater Diatoms. Water Quality Branch, Ontario Ministry of the Environment, Toronto, Ontario, 517 pp.

Bennett, K.D. 1996. Determination of the number of zones in a biostratigraphical sequence. New Phytologist, 132: 155-170.

Cearreta, A., Cachão, M., Cabral, M.C., Bao, R. and Ramalho, M.J. 2003. Lateglacial and Holocene environmental changes in Portuguese coastal lagoons 2: microfossil multiproxy reconstruction of the Santo André coastal area. The Holocene, 13: 447-458.

Clark, J.A., Farrel, W.E. and Peltier, W.R. 1978. Global changes in postglacial sea level: a numerical calculation. Quaternary Research, 9: 265-287.

Cooper, J.A.G. 1994. Lagoons and microtidal coasts. In: Coastal Evolution. Late Quaternary Shoreline Morphodynamics (Eds R.W.G. Carter and C.D. Woodroffe), pp. 219-265. Cambridge University Press, Cambridge.

Davis, R.A.J. and Fitzgerald, D.M. 2004. Beaches and Coasts. Blackwell Science, Oxford, 419 pp.

De Groot, T.A.M. and Orford, J.D. 2000. Implications for coastal zone management. In: Sea-Level Change and Coastal Processes. Implications for Europe (Eds D. Smith, S.B. Raper, S. Zerbini and A. Sánchez-Arcilla), pp. 214-242. Office for Official Publications of the European Communities, Luxembourg. 
De Wolf, H. 1982. Method of coding of ecological data from diatoms for computing utilization. Mededelingen Rijks Geologische Dienst, 36: 95-99.

Delgado, I., Alcántara-Carrió, J., Alejo, I., Alonso, I. and Louzao, M. 2002. Influence of hydrodynamics and sedimentary characteristics of Barqueiro Ria on Arealonga Beach dynamics. Journal of Coastal Research, SI 36: 231-239.

Denys, L. 1991a. A check-list of the diatoms in the Holocene deposits of the western Belgian coastal plain with a survey of their apparent ecological requirements. I. Introduction, ecological code and complete list. Belgische Geolgische Dienst. Professional Paper, 246: 1-41.

Denys, L. 1991b. A check-list of the diatoms in the Holocene deposits of the western Belgian coastal plain with a survey of their apparent ecological requirements. II. Centrales. Belgische Geolgische Dienst. Professional Paper, 247: 1-92.

Denys, L. and De Wolf, H. 1999. Diatoms as indicators of coastal paleoenvironments and relative sea-level change. In: The Diatoms: Applications for the Environmental and Earth Sciences (Eds E.F. Stoermer and J.P. Smol), pp. 277-297. Cambridge University Press, Cambridge.

Devoy, R.J.N., Delaney, C., Carter, R.W.G. and Jennings, S.C. 1996. Coastal stratigraphies as indicators of environmental changes upon European Atlantic coasts in the Late Holocene. Journal of Coastal Research, 12: $564-588$.

Dias, J.M.A., Boski, T., Rodrigues, A. and Magalhães, F. 2000. Coast line evolution in Portugal since the Last Glacial Maximum until present-a synthesis. Marine Geology, 170: 177-186.

Earle, J.C. and Duthie, H.C. 1986. A multivariate statistical approach for interpreting marshland diatom succession. In: Proceedings of the 8th International Diatom Symposium (Ed M. Ricard), pp. 441-458. Otto Koeltz, Koenigstein.

Freitas, M.C. and Andrade, C. 2005. Global vs local forcing factors and paleoenvironmental changes of estuaries and lagoons of SW Portugal since the late Glacial. In: Coastal Hope Conference Proceedings (Ed M.C. Freitas), pp. 64-70. Universidade de Lisboa, Lisbon.

Freitas, M.C., Andrade, C. and Cruces, A. 2002. The geological record of environmental changes in southwestern Portuguese coastal lagoons since the Lateglacial. Quaternary International, 93-94: 161170.

Freitas, M.C., Andrade, C., Rocha, F., Tassinari, C., Munhá, J.M., Cruces, A. and Vidinha, J. 2003.
Lateglacial and Holocene environmental changes in Portuguese coastal lagoons. 1: the sedimentological and geochemical records of the Santo André coastal area. The Holocene, 13: 433-446.

González-Álvarez, R., Bernárdez, P., Pena, L.D., Francés, G., Prego, R., Diz, P. and Vilas, F. 2005. Paleoclimatic evolution of the Galician continental shelf (NW of Spain) during the last 3000 years: from a storm regime to present conditions. Journal of Marine Systems, 54: 245-260.

Grimm, E.C. 1987. CONISS: a Fortran 77 program for stratigraphically constrained cluster analysis by the method of incremental sum of squares. Computers and Geosciences, 13: 13-35.

Hemphill-Haley, E. 1996. Diatoms as an aid in identifying late-Holocene tsunami deposits. The Holocene, 6: 439-448.

Hesp, P.A. and Short, A.D. 1999. Barrier morphodynamics. In: Handbook of Beach and Shoreface Morphodynamics (Ed A.D. Short), pp. 307333. John Wiley and Sons, Chichester.

Hustedt, F. 1937-1939. Systematische und okologische Untersuchungen uder den Diatomeen-Flora von Java, Bali, Sumatra. Archiv für Hydrobiologie (Suppl.), 15 $\& 16$.

Hustedt, F. 1957. Die Diatomeenflora des Fluss-systems der Weser im Gebiet der Hansestadt Bremen. Abhandlungen herausgegeben von Naturwissennchaftlichen Verein zu Bremen, 34: 181440 .

IPCC Intergovernmental Panel on Climate Change (Ed). 2001. Climate Change 2001: The Scientific Basis. Cambridge University Press, Cambridge, 881 pp.

Isla, F.I. 1995. Coastal lagoons. In: Geomorphology and Sedimentology of Estuaries (Ed G.M.E. Perillo), pp. 241-272. Elsevier, Amsterdam.

Kjemperud, A. 1982. Late Weichselian and Holocene shoreline displacement in parts of Trøndelag, central Norway. Thesis, Universitetet i Oslo, Oslo.

Kjemperud, A. 1986. Late Weichselian and Holocene shoreline displacement in the Trondheimsfjord area, central Norway. Boreas, 15: 61-82.

Kjerfve, B. 1994. Coastal lagoons. In: Coastal Lagoon Processes (Ed B. Kjerfve), pp. 1-8. Elsevier, Amsterdam.

Krammer, K., 2000. The Genus Pinnularia. In: H. LangeBertalot (Editor), Diatoms of the European Inland Waters and Comparable Habitats. Volume 1. A. R. G. Gantner Verlag, Ruggell, Liechtenstein, 703 pp. 
Krammer, K., 2002. Cymbella. In: H. Lange-Bertalot (Editor), Diatoms of the European Inland Waters and Comparable Habitats. Volume 3. A. R. A. Gantner Verlag, Ruggell, Liechtenstein, 584 pp.

Krammer, K., 2003. Cymbopleura, Delicata, Navicymbula, Gomphocymbellopsis, Afrocymbella. In: H. Lange-Bertalot (Editor), Diatoms of the European Inland Waters and Comparable Habitats. Volume 4. A. R. A. Gantner Verlag, Ruggell, Liechtenstein, 530 pp.

Krammer, K. and Lange-Bertalot, H. 1986-1991. Bacillariophyceae. In: Süßwasserflora von Mitteleuropa (Eds H. Ettl, J. Gerloff, H. Heynig and D. Mollenhauer), 2. Fischer-Verlag, Stuttgart.

Lange-Bertalot, H., 2001. Navicula sensu stricto, 10 Genera Separated from Navicula sensu lato, Frustulia. In: H. Lange-Bertalot (Editor), Diatoms of the European Inland Waters and Comparable Habitats. Volume 2. A. R. G. Gantner Verlag, Ruggell, Liechtenstein, $526 \mathrm{pp}$.

Lankford, R. 1977. Coastal lagoons of Mexico: their origin and classification. In: Estuarine Processes (Ed M. Wiley), pp. 182-215. Academic Press, New York.

Lorenzo, F., Alonso, A. and Pagés, J.L. 2003. Evolución y erosión comparada de tres sistemas playa/flecha en las rías de Ortigueira, O Barqueiro y Viveiro (Galicia, España). Revista de Cuaternario y Geomorfología, 17: 75-89.

Lorenzo, F., Alonso, A. and Pagés, J.L. in press . Erosion and accretion of beach/spit systems in northwest Spain: a response to human activity. Journal of Coastal Research.

Lozano, I., Devoy, R.J.N., May, W. and Andersen, U. 2004. Storminess and vulnerability along the Atlantic coastlines of Europe: analysis of storm records and of greenhouse gases induced climate scenario. Marine Geology, 210: 205-225.

Martínez Cortizas, A. and Pérez Alberti, A. (Eds). 1999. Atlas Climático de Galicia. Xunta de Galicia, Santiago de Compostela, 207 pp.

Masselink, G. and Turner, I. L. 1999. The effects of tides on beach morphodynamics. In: Handbook of Beach and Shoreface Morphodynamics (Ed A. D. Short), pp. 204-229. John Wiley \& Sons, Chichester.

Nichols, M.M. 1989. Sediment accumulation rates and relative sea-level rise in lagoons. Marine Geology, 88: 201-219.

Nichols, M.M. and Boon, J.D. 1994. Sediment transport processes in coastal lagoons. In: Coastal Lagoon Processes (Ed B. Kjerfve), pp. 157-220. Elsevier, Amsterdam.
Overpeck, J.T., Otto-Bliesner, B.L., Miller, G.H., Muhs, D.R., Alley, R.B. and Kiehl, J.T. 2006. Paleoclimatic evidence for future ice-sheet instability and rapid sealevel rise. Science, 311: 747-750.

Pagés, J.L., Alonso, A., Cearreta, A., Hacar, M. and Bao, R. 2003. The Holocene record in the Villaviciosa Estuary (Asturias, Spain). In: Quaternary Climatic Changes and Environmental Crises in the Mediterranean Region (Eds M.B. Ruiz Zapata, M. Dorado Valiño, A. Valdeolmillos Rodríguez, M.J. Gil García, T. Bardají Azcárate, I. de Bustamante Gutiérrez \& I. Martínez Mendizábal), pp. 249-256. Universidad de Alcalá de Henares, Madrid.

Pagés, J.L., Alonso, A. and Garzón, G. 2005. Holocene transgression in the western Bay of Biscay, Spain. In: INQUA - IGCP International Conference. Late Quaternary Coastal Changes, Sea Level, Sedimentary Forcing and Anthropogenic Impacts (Ed C. Baeteman), pp. 77-78, Dunkirk.

Parsons, M. 1998. Salt marsh sedimentary record of the landfall of Hurricane Andrew on the Louisiana coast: diatoms and other paleoindicators. Journal of Coastal Research, 14: 939-950.

Reed, J., Roberts, N. and Leng, M. 1999. An evaluation of the diatom response to Late Quaternary environmental change in two lakes in the Konya Basin, Turkey, by comparison with stable isotope data. Quaternary Science Reviews, 18: 631-646.

Reimer, P.J., Baillie, M.G.L., Bard, E., Bayliss, A., Beck, J.W., Bertrand, C.J.H., Blackwell, P.G., Buck, C.E., Burr, G.S., Cutler, K.B., Damon, P.E., Edwards, R.L., Fairbanks, R.G., Friedrich, M., Guilderson, T.P., Hogg, A.G., Hughen, K.A., Kromer, B., McCormac, G., Manning, S., Ramsey, C.B., Reimer, R.W., Remmele, S., Southon, J.R., Stuiver, M., Talamo, S., Taylor, F.W., van der Plicht, J. and Weyhenmeyer, C.E. 2004. IntCal04 Terrestrial Radiocarbon Age Calibration, 0-26 Cal Kyr BP. Radiocarbon, 46: 10291058.

Renberg, I. 1990. A procedure for preparing large sets of diatom slides from sediment cores. Journal of Paleolimnology, 4: 87-90.

Santos, L., Bao, R. and Sánchez-Goñi, M.F. 2001. Pollen record of the last 500 years from the Doniños coastal lagoon (NW Iberian Peninsula): changes in the pollinic catchment size versus palaeoecological interpretation. Journal of Coastal Research, 17: 705713.

Saulnier-Talbot, E. and Pienitz, R. 2001. Isolation au postglaciaire d'un bassin côtier près de KuujjuaraapikWhapmagoostui, en Hudsonie (Québec): une analyse biostratigraphique diatomifère. Géographie Physique et Quaternaire, 55: 63-74. 
Smol, J.P. 1992. Paleolimnology: an important tool for effective ecosystem management. Journal of Aquatic Ecosystem Health, 1: 49-58.

Smol, J.P. 2002. Pollution of Lakes and Rivers. A Palaeoenvironmental Perspective. Arnold Publishers, London, $280 \mathrm{pp}$.

Spencer, C.D., Plater, A.J. and Long, A.J. 1998. Rapid coastal change during the mid- to late Holocene: the record of barrier estuary sedimentation in the Romney Marsh region, southeast England. The Holocene, 8: 143-163.

Stabell, B. 1985. The development and succession of taxa within the diatom genus Fragilaria Lyngbye as a response to basin isolation from the sea. Boreas, 14: 273-286.

Van Dam, H., Mertens, A. and Sinkeldam, J. 1994. A coded checklist and ecological indicator values of freshwater diatoms from The Netherlands. Netherlands Journal of Aquatic Ecology, 28: 117-133.

Vilas, F. and Rolán, E. 1985. Caracterización de las lagunas costeras de Galicia, N.W. Península Ibérica, España. In: Actas I $^{\circ}$ Congreso Ibérico de Quaternario, pp. 253-268, Lisboa.

Vilas, F., Sopeña, A., Rey, L., Ramos, A., Nombela, M.A. and Arche, A. 1991. The Corrubedo beach-lagoon complex, Galicia, Spain: Dynamics, sediments and recent evolution of a mesotidal coastal embayment. Marine Geology, 97: 391-404.

Vilas, F., Nombela, M.A., Alejo, I., García, S., Rubio, B., Ferrero, M. and Pazos, O. 1995. Evaluación del estado actual de la línea de costa en las Rías Bajas, Galicia (España). In: Actas $3^{\mathrm{a}}$ Reuniâo do Quaternario Iberico, pp. 355-359. Universidade de Coimbra, Coimbra.
Vos, P.C. and De Wolf, H. 1988. Methodological aspects of paleoecological diatom research in coastal areas of the Netherlands. Geologie en Mijnbouw, 67: 31-40.

Vos, P.C. and De Wolf, H. 1993. Diatoms as a tool for reconstructing sedimentary environments in coastal wetlands: methodological aspects. Hydrobiologia, 269/270: 285-296.

Vos, P.C. and De Wolf, H. 1994. Palaeoenvironmental research on diatoms in early and middle Holocene deposits in central north Holland (The Netherlands). Netherlands Journal of Aquatic Ecology, 28: 97-115.

Wheeler, B.D., Money, R.P. and Shaw, S.C., 2002. Freshwater wetlands. In: M.R. Perrow and A.J. Davy (Editors), Handbook of Ecological Restoration. Cambridge University Press, Cambridge, pp. 325-354.

Witkowski, A., Lange-Bertalot, H. and Metzeltin, D. 2000. Diatom Flora of Marine Coasts I. Koeltz Scientific Books, Königstein, 925 pp.

Zazo, C., Goy, J.L., Lario, J. and Silva, P.G. 1996. Littoral zone and rapid climatic changes during the last 20,000 years. The Iberia study case. Zeitschrift fur Geomorphologie, 102: 119-134.

Zong, Y. and Horton, B.P. 1999. Diatom-based tidal-level transfer functions as an aid in reconstructing Quaternary history of sea-level movements in the UK. Journal of Quaternary Science, 14: 153-167.

Zong, Y. and Tooley, M.J. 1999. Evidence of midHolocene storm-surge deposits from Morecambe Bay, northwest England: A biostratigraphical approach. Quaternary International, 55: 43-50. 